\title{
Pemberdayaan Kelompok Masyarakat Pesisir Melalui Budi Daya Rumput Laut Metode Vertikultur di Kawasan Perdesaan Tumbuh Lestari Desa Rambu-rambu, Kabupaten Konawe Selatan
}

\section{(Empowering Coastal Community Groups in Rambu-rambu Village, Tumbuh Lestari Rural Area, South Konawe District)}

\author{
Nur Irawati*, Asriyana \\ Jurusan Manajemen Sumberdaya Perairan, Fakultas Perikanan dan Ilmu Kelautan, Universitas Halu Uleo, Kampus Bumi \\ Tridharma, Anduonohu, Kec. Kambu, Kota Kendari, Sulawesi Tenggara 93232. \\ Penulis Korespondensi: nur.irawati@uho.ac.id \\ Diterima September 2019/Disetujui April 2020
}

\begin{abstract}
ABSTRAK
Desa Rambu-rambu merupakan salah satu desa yang masuk dalam Kawasan Perdesaan Tumbuh Lestari, Kabupaten Konawe Selatan. Tujuan dari kegiatan pengabdian ini adalah mengadakan pemberdayaan masyarakat pesisir melalui kegiatan budi daya rumput laut metode vertikultur menggunakan kurungan. Program Pengabdian Kepada Masyarakat (PKM) melalui kegiatan Kuliah Kerja Nyata Pemberdayaan Pembelajaran Mahasiswa (KKN PPM) berlangsung selama 30 hari dari 29 Juni-28 Juli 2019. Kegiatan ini terdiri 3 tahapan, yaitu penyuluhan kegiatan, persiapan training, dan pelaksanaan training budi daya rumput laut. Kegiatan ini melibatkan 20 mahasiswa KKN PPM dan 42 masyarakat pesisir yang terdiri dari nelayan, instri nelayan, dan petani. Peningkatan pengetahuan dan keterampilan selama kegiatan KKN PPM diperoleh sebelum kegiatan sebanyak 66,7\% yang tidak paham, setelah kegiatan menjadi $71,4 \%$ yang paham terhadap budi daya rumput laut metode vertikultur. Peningkatan keterampilan dari sebelum kegiatan sebanyak $81 \%$ yang tidak terampil, setelah kegiatan menjadi $61,9 \%$ yang terampil dalam kegiatan budi daya rumput laut metode vertikultur. Peningkatan pengetahuan masyarakat ini terlihat dari mampunya mereka menjelaskan dengan baik tentang jenis-jenis rumput laut, manfaat dari rumput laut, dan ciri-ciri bibit rumput laut yang baik untuk budi daya rumput laut. Sedangkan peningkatan keterampilan terlihat dari kemampuan mitra dalam membuat rakit budi daya rumput laut, kurungan rumput laut, pengikatan bibit rumput laut, dan pengamatan kualitas perairan di area budi daya rumput laut. Capaian akhir dari kegiatan ini adalah adanya peningkatan pengetahuan dan keterampilan mengenai budi daya rumput laut metode vertikultur menggunakan kurungan.
\end{abstract}

Kata kunci: Konawe Selatan, kurungan sistem vertikultur, masyarakat pesisir, rumput laut

\begin{abstract}
Rambu-rambu Village is one of the villages clustered within the Tumbuh Lestari rural area of North Konawe District. The main purpose of this project was to empower the coastal community groups in Rambu-rambu Village through the introduction of in-cage verticulture farming of seaweed. The project was carried out within the scheme of Community Service Program (PKM/Pengabdian Kepada Masyarakat) funded by the University of Halu Oleo. The project lasted for 30 days from 29 June to 28 July 2019. The activity consisted of three stages, are initial dissemination activity, preparation of the training, and implementation of training of seaweed culture. The project involved 20 students of the University of Halu Oleo and 42 people from fishermen, fisherme wifes, and farmer groups. Before the training was conducted $66.7 \%$ of the participants did not have the knowledge and after the training $71.4 \%$ of the respondents gained an understanding regarding the seaweed verticulture farming method. The improvement of skill was also evident where before the training, $81 \%$ of the participants were not able to do seaweed farming method and after the training, $61.9 \%$ of the participants were capable or skilled of repeating the seaweed verticulture method. The increased knowledge of the participants could be described from their ability to clearly explain types of seaweed species used, the benefits of seaweed, and the characteristics of high quality of seaweed seed. The improved skill of the participants were al so observed from their skill in constructing the seaweed raft and seaweed net cage, tying up the seaweed seed, and conducting the observation of water quality condition in the location of seaweed farming. The result of this activity showed an increased of knowledge and skill of the trained participants regarding seaweed farming using verticulture method.
\end{abstract}

Keywords: coastal community, in-cage verticulture, seaweed, South Konawe 


\section{PENDAHULUAN}

Kecamatan Kolono merupakan salah satu kecamatan yang berada di Kabupaten Konawe Selatan yang mempunyai sumber daya alam yang memadai, khususnya cadangan batu marmer, energi panas bumi, kayu jati, dan hasil-hasil laut yang melimpah. Daerah ini juga mempunyai teluk, yaitu Teluk Kolono yang sangat strategis, karena berada didekat kabupaten Muna dan Buton utara tempat lalu lintas perhubungan laut ke Indonesia Timur. Selain itu, tempat ini juga mempunyai pelabuhan penyeberangan Amolengu (Kolono Timur)-Labuan (Buton Utara). Kondisi ini sangat cocok untuk investasi di bidang transportasi laut dan hasil-hasil perikanan. Masyarakat yang tinggal di perairan Teluk Kolono telah lama memanfaatkan teluk tersebut sebagai tempat mencari ikan untuk kebutuhan hidup mereka. Alat tangkap yang mereka gunakan dalam melakukan penangkapan antara lain pancing rawai, bubu, sero, panja, bangang, dan pancing tenggiri, sedangkan untuk kegiatan budi daya, yaitu budi daya rumput laut dan budi daya Lobster. Hasil tangkapan nelayan selain dikonsumsi juga dijual pada pengumpul untuk memenuhi kebutuhan sehari-hari (Kemendesa 2017).

Desa Rambu-rambu adalah salah satu desa yang berada di pesisir Teluk Kolono. Desa ini memiliki penduduk dengan matapencaharian sebagai nelayan dan petani. Desa ini menjadi salah satu desa dari lima desa yang dipilih oleh Pemerintah Kabupaten Konawe Selatan sebagai Kawasan Perdesaan Tumbuh Lestari, Kabupaten Konawe Selatan. Kawasan ini dibentuk berdasarkan kesepakatan lima kepala desa, yaitu Desa Meletumbo, Roda, Lamapu, Rambu-rambu, dan Lambangi yang ditandatangani di atas berita acara pada tanggal 20 September 2016. Surat kesepakatan antar desa tersebut berisi tentang penetapan kawasan perdesaan. Pada pengelolaan pembangunan kawasan perdesaan, kawasan Tumbuh Lestari mencakup pengembangan pada empat cluster di antaranya adalah perikanan tangkap, budi daya, ternak sapi, jambu mete, kelapa, dan jati. Pengembangan empat cluster ini dalam penyusunan program meliputi lima bidang, yaitu pembangunan peningkatan infrastruktur, penguatan kelembagaan, inovasi teknologi, dan peningkatan kapasitas SDM. Adapun RPKP ini merupakan rancangan untuk lima tahun ke depan (Kemendesa 2017).

Posisi Kawasan Perdesaan Tumbuh Lestari dalam konteks regional merupakan kelanjutan strategi pengembangan wilayah di Indonesia. Posisi Kawasan Perdesaan Tumbuh Lestari memainkan peranan penting dalam pola pergerakan orang dan barang di wilayah regional Sulawesi Tenggara dan Sulawesi. Pola pergerakan barang antara Kawasan Perdesaan Tumbuh Lestari terkoneksi kuat dan saling memengaruhi. Kawasan Perdesaan Tumbuh Lestari merupakan daerah hulu yang menjadi sumber komoditi pertanian dan perikanan serta kelautan yang keluar-masuk di pelabuhan Kota Kendari sebagai hilir, lalu terdistribusi ke kotakota lain di Sulawesi. Hal ini tentu menjadi peluang besar bagi Kawasan Perdesaan Tumbuh Lestari untuk mendistribusikan produk-produk hasil olahan komoditas pertanian dan perikanan ke pasar regional Sulawesi Tenggara dan Sulawesi pada umumnya.

Dari keempat cluster yang menjadi pilar dalam pengembangan Kawasan Perdesaan Tumbuh Lestari maka potensi bidang perikanan tangkap dan budi daya menjadi salah satu potensi yang dirasa paling bermanfaat dan potensial. Hal ini didasari pada dua pertimbangan utama, yaitu pertama dominan mata pencaharian masyarakat Kawasan Perdesaan Tumbuh Lestari sebagai nelayan, sehingga pengembangan potensi perikanan tangkap dan budi daya akan dapat dirasakan langsung oleh sebagian besar masyarakat. Kedua, komoditi hasil perikanan juga merupakan konsumsi utama masyarakat setempat, sehingga dengan meningkatkan potensi ini tidak hanya menunjang kegiatan ekonomi masyarakat tetapi juga kebutuhan konsumsi masyarakat setempat. Kegiatan budi daya masih sangat kurang dilakukan oleh masyarakat dari keempat potensi yang dimiliki di kawasan tersebut. Masyarakat hanya bertumpu pada kegiatan penangkapan perikanan saja. Hal ini didasarkan karena masih kurangnya pengetahuan dan informasi tentang kegiatankegiatan budi daya yang dapat dikembangkan di kawasan tersebut.

Kegiatan budi daya di Teluk Kolono merupakan kegiatan yang sudah lama tidak dilakukan lagi oleh masyarakat petani di Desa Rambu-rambu. Keberadaan bibit menjadi salah satu sebab karena untuk memperoleh bibit membutuhkan jarak yang jauh dan kualitas bibit yang digunakan masih bibit yang umum digunakan oleh petani rumput laut, yaitu bibit rumput laut ini hanya bisa dipakai sampai 6-7 kali pemanenan, setelah itu produksi rumput laut akan menurun. Penyakit dan hama rumput laut pun juga dikeluhkan oleh pembudidaya rumput 
laut di desa ini. Permasalah lainnya adalah pemasaran rumput laut, di mana saat panen rumput laut melimpah dan harga rumput laut akan sangat jatuh, sehingga menyebabkan banyak petani rumput laut yang merugi.

Melihat potensi yang dimiliki Desa Ramburambu, Kecamatan Kolono dan permasalahan yang dihadapi, maka tim pengabdian masyarakat dari Universitas Halu Oleo, khususnya Fakultas Perikanan dan Ilmu Kelautan (FPIK) melaksanakan kegiatan KKN PPM (Kuliah Kerja Nyata Pemberdayaan Pembelajaran Mahasiswa). Kegiatan KKN PPM ini bertujuan untuk mengadakan pemberdayaan masyarakat pesisir melalui kegiatan budi daya rumput laut metode vertikultur menggunakan kurungan.

\section{METODE PELAKSANAAN KEGIATAN}

\section{Waktu Dan Tempat}

Program Pengabdian Kepada Masyarakat (PKM) melalui kegiatan KKN PPM berlangsung selama 30 hari dari 29 Juni-28 Juli 2019. Kegiatan ini dilaksanakan di Desa Rambu-rambu, Kecamatan Kolono Timur, Kabupaten Konawe Selatan, Sulawesi Tenggara. Desa Rambu-rambu adalah salah satu desa yang berada di pesisir Teluk Kolono. Desa ini menjadi salah satu desa dari lima desa yang dipilih oleh Pemerintah Kabupaten Konawe Selatan sebagai Kawasan Perdesaan Tumbuh Lestari, Kabupaten Konawe Selatan. Penetapan kawasan ini selain disebabkan penduduknya yang bermata pencaharian sebagai nelayan dan petani, juga terdapatnya potensi yang cukup besar di bidang perikanan tangkap dan budibdaya, khususnya budibdaya rumput laut. Kegiatan ini melibatkan 20 mahasiswa KKN PPM dan 42 masyarakat pesisir yang terdiri dari nelayan, instri nelayan, dan petani di Desa Rambu-rambu.

\section{Alat dan Bahan}

Alat dan bahan yang digunakan dalam kegiatan KKN PPM ini disajikan pada Tabel 1.

\section{Metode Pelaksanaan}

Metode pelaksanaan kegiatan KKN PPM terdiri dari persiapan dan pembekalan mahasiswa KKN PPM serta pelaksanaan program KKN PPM.

\section{- Persiapan dan pembekalan}

Persiapan dan pembekalan meliputi mekanisme persiapan pelaksanaan kegiatan $\mathrm{KKN}$ PPM dan materi persiapan dan pembekalan KKNPPM yang perlu diberikan kepada mahasiswa. KKN PPM merupakan KKN dengan tema atau program tertentu. KKN ini merupakan kerja sama antara mahasiswa KKN dan dosen dalam pelaksanaan pengabdian pada masyarakat. Biasanya dalam KKN ini program kegiatannya sudah jelas dengan dukungan dana dari Kemenristek ataupun DRPM.

Mekanisme persiapan pelaksanaan kegiatan KKN PPM dilakukan melalui dua tahapan, yaitu penentuan lokasi dan pemilihan mahasiswa peserta KKN PPM. Penentuan lokasi dilakukan dengan melihat potensi dan permasalahan yang

Tabel 1 Alat dan bahan pada kegiatan budi daya rumput laut metode vertikultur menggunakan kurungan

\begin{tabular}{ll}
\hline \multicolumn{1}{c}{ Alat dan bahan } & \multicolumn{1}{c}{ Kegunaan } \\
\hline Alat & \\
\hline LCD & Media presentasi \\
Perahu & Alat transportasi pengangkutan dan pengamatan rumput laut \\
Meteran & Alat ukur panjang \\
Timbangan & Pengukuran berat bibit rumput laut \\
Pisau & Alat pemotong bibit rumput laut \\
Thermometer & Pengukuran suhu air \\
Handrefraktometer & Pengukuran salinitas air \\
pH meter & Pengukuran pH air \\
Piring secchi & Pengukuran kecerahan \\
Pelampung dan stopwatch & Pengukuran kecepatan arus \\
Pelampung & Pelindung diri \\
\hline Bahan & \\
\hline Kappaphycus alvarezii & Rumput laut yang dibudidayakan \\
Bambu & Pembuatan rangka kurungan \\
Jaring & Dinding kurungan \\
Tali ris berbagai ukuran & Rakit budidaya rumput laut dan tali pengikat rumput laut \\
Pelampung rakit & Menjaga keseimbangan rumput laut di kolom air \\
Pemberat & Menjaga keseimbangan rumput laut di kolom air \\
\hline
\end{tabular}


ada di daerah tersebut, serta mencari alternatif pemecahan permasalahannya dengan didasarkan pada potensi sumber daya manusia dalam hal ini dosen dan mahasiswa. Selain itu lokasi yang terjangkau, kondisi masyarakat yang masih tertinggal, serta keberpihakan pemerintah daerah dan masyarakat dalam menerima kegiatan tersebut. Berdasarkan hal tersebut di atas, maka Desa Rambu-rambu yang masuk dalam Kawasan Tumbuh Lestari menjadi pilihan lokasi dalam kegiatan KKN PPM ini.

Pemilihan mahasiswa sebagai peserta KKN PPM dilakukan oleh program studi yang ada di FPIK, yaitu Program Studi Manajemen Sumberdaya Perairan, Budidaya Perairan, Perikanan Tangkap, Ilmu Kelautan, Oseanografi, dan Teknologi Hasil Perikanan. Selanjutnya diajukan kepada Unit Pelaksana Teknis Mata Kuliah Umum Universitas Halu Oleo (UPT MKU UHO) melalui pendaftaran online pada website http://www.uho.ac.id/kkn. Hasil dari seleksi pemilihan mahasiswa ditentukan 20 orang mahasiswa yang ikut dalam kegiatan ini, yaitu dari Program Studi Manajemen Sumberdaya Perairan, Budidaya Perairan, Perikanan Tangkap, dan Teknologi Hasil Perikanan.

Materi persiapan yang berupa pembekalan KKN akan dilakukan sebelum rombongan KKN berangkat ke lokasi yang telah ditentukan. Pelaksanaan pembekalan dilakukan pada tanggal 25 Juni 2019, bertempat di ruang kuliah FPIK Universitas Halu Oleo. Pembekalan diberikan oleh ketua jurusan dari masing-masing fakultas dan dosen pembimbing KKN. Ketua jurusan dalam hal ini memberikan pembekalan dengan materi tentang masyarakat dan budaya kehidupan desa. Hal tersebut diberikan dengan tujuan sebagai pembekalan kepada mahasiswa jika berhadapan dengan masyarakat umum yang mempunyai karakter dan pembawaan yang berbeda dengan kehidupan kampus.

Pembimbing KKN bertugas memberikan bimbingan teknis seputar kegiatan pengabdian yang akan dilaksanakan di Desa Rambu-rambu. Bimbingan yang diberikan berupa pelaksanaan aplikasi metode vertikultur dalam budi daya rumput laut. Sebelum materi tersebut dipraktikkan di desa tempat KKN, peserta program KKN PPM terlebih dahulu melakukan uji coba atau praktik di kampus. Hal tersebut bertujuan untuk mensukseskan program dan menghindari bias atau halangan-halangan yang mungkin terjadi di lokasi (Gambar 1).

\section{- Pelaksanaan}

Dalam pelaksanaan kegiatan KKN-PPM, langkah-langkah program yang direncanakan untuk mencapai hasil yang telah ditentukan, meliputi tiga tahapan, yaitu tahap persiapan, pelaksanaan dan hasil (output). Pada tahap persiapan, kegiatan yang dilaksanakan meliputi peninjauan lokasi KKN-PPM. Hal ini dimaksudkan untuk melihat kondisi dari Desa Ramburambu dan penentuan pontensi, permasalahan serta solusi terhadap permasalahan tersebut.

Pada tahap pelaksanaan dilakukan tiga kegiatan, yaitu penyuluhan kegiatan, persiapan training, dan pelaksanaan training budi daya rumput laut. Kegiatan penyuluhan berisi tentang pengenalan budi daya rumput laut metode vertikultur dan sosialisasi pelaksanaan kegiatan budi daya rumput laut di lapangan. Pada kegiatan penyuluhan dilakukan dengan menggabungkan beberapa metode, yaitu metode presentasi, diskusi, dan problem solving. Kegiatan kedua adalah pelaksanaan kegiatan budi daya rumput laut dengan metode vertikultur menggunakan kurungan di lapangan meliputi kegiatan persiapan bibit dan penanaman.

Pada kegiatan persiapan training, bibit yang digunakan dari jenis rumput laut Kappaphycus alvaresi. Bibit diambil dari hasil panen petani rumput laut di sekitar lokasi pengabdian yang telah ditanam atau dibudidayakan selama satu bulan. Bibit rumput laut yang sudah disiapkan terlebih dahulu dibersihkan dari kotorankotoran atau organisme penempel. Kondisi rumput laut yang dipilih adalah yang muda, segar, bersih, serta bebas dari jenis rumput laut lainnya. Bobot awal bibit yang digunakan adalah 50g/ikat (Aslan \& Rahman 2010b).

Pada pelaksanaan training budi daya rumput laut, dipersiapkan wadah budi daya berupa bangunan tali-temali mengapung di permukaan perairan laut, berbentuk persegi empat dengan

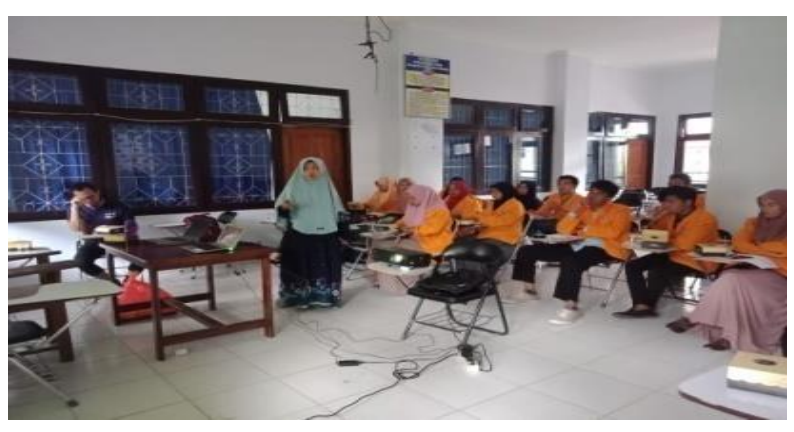

Gambar 1 Kegiatan pembekalan mahasiswa KKNPPM. 
ukuran sekitar 20 × 30 m (Gambar2). Pemasangan tali gantung yang telah dipersiapkan sebelumnya diikatkan pada tali ris utama dengan interval 1,5 $\mathrm{m}$ dan jarak antar tali gantung/vertikal $1 \mathrm{~m}$. Panjang tali vertikultur adalah $150 \mathrm{~cm}$ (termasuk pemberat). Konstruksi dilengkapi dengan pelampung styrofoam sebagai pengapung rakit dan jangkar beton yang berukuran $70 \times 70 \mathrm{x}$ $70 \mathrm{~cm}^{3}$ sebagai penahan konstruksi agar tetap stabil dan tidak terbawa arus. Selanjutnya dilakukan pemasangan bibit yang telah disiapkan dengan berat $50 \mathrm{~g} / \mathrm{ikat}$, ditanam/ikat pada tali vertikal dengan jarak $25 \mathrm{~cm}$. Metode yang digunakan adalah metode jerat yang bernama lup pendek atau biasa disebut made loop mengikuti nama Made Simbik dari Bali. Metode made loop merupakan cara pengikatan tali dengan simpul (Aslan \& Rahman 2010; Pong-Masak \& Sarira 2018). Pengembangan budi daya rumput laut dengan metode vertikultur yang dilaksanakan pada kegiatan KKN-PPM ini dengan menambahkan kurungan. Hal ini dimaksudkan agar rumput laut yang tumbuh lebih bersih dari alga penempel lainnya dan terhindar dari predator terutama ikan beronang dan bulu babi. Bibit yang telah diikat selanjutnya dimasukkan ke dalam kurungan yang berbentuk seperti tabung (Gambar 2). Rangka kurungan terbuat dari bambu dan ditutupi oleh waring. Agar pelatihan ini terus berkelanjutan, tim pengabdian memberikan bibit rumput laut kepada para kelompok masyarakat yang merupakan hasil dari kegiatan budi daya rumput laut metode vertikal, untuk menerapkan metode yang telah dicontohkan pada program KKN-PPM ini.

Tahap akhir adalah hasil (output) dilakukan untuk mengetahui tingkat penguasaan pengetahuan dan keterampilan masyarakat Desa
Rambu-rambu terhadap kegiatan pengabdian yang dilaksanakan di Desa tersebut. Pelaksanaan tahap ini, dilakukan dengan mewawancarai masyarakat yang hadir pada kegiatan peyuluhan di balai desa dan pelaksanaan budi daya di lapangan. Kegiatan wawancara dilakukan dua kali, yaitu sebelum kegiatan dan setelah kegiatan penyuluhan dan pelaksanaan budi daya. Kegiatan wawancara dilakukan dua kali dengan maksud untuk melihat perubahan terhadap pengetahuan dan keterampilan masyarakat. Jumlah responden yang diwawancarai sebanyak 15 responden dari jumlah 42 peserta yang hadir pada kegiatan penyuluhan dan 6 responden pada kegiatan pelaksanaan budi daya di lapangan. Materi wawancara yang digunakan menyangkut pengetahuan dan keterampilan tentang budi daya rumput metode vertikultur, yaitu jenis-jenis rumput laut, pemanfaatan rumput laut, pemilihan bibit rumput laut, pembuatan rakit budi daya, pengikatan bibit rumput laut, penanaman bibit rumput laut, dan kualitas air.

\section{Analisis Data}

Hasil wawancara yang diperoleh, selanjutnya di analisis menggunakan content analysis dan analisis distribusi frekuensi. Content analysis digunakan untuk mengkategorisasi jawaban responden atas pertanyaan-pertanyaan dalam kuisiner menjadi dua group tematik, yaitu pengetahuan dan keterampilan. Selanjutnya analisis distribusi frekuensi digunakan untuk menentukan prosentase seberapa besar penguasaan pengetahuan dan keterampilan responden. Klasifikasi penguasaan pengetahuan dibagi atas tiga kategori, yaitu tidak paham, sedikit paham, dan paham. Penguasaan keterampilan dibagi atas tiga kategori, yaitu tidak terampil, sedikit

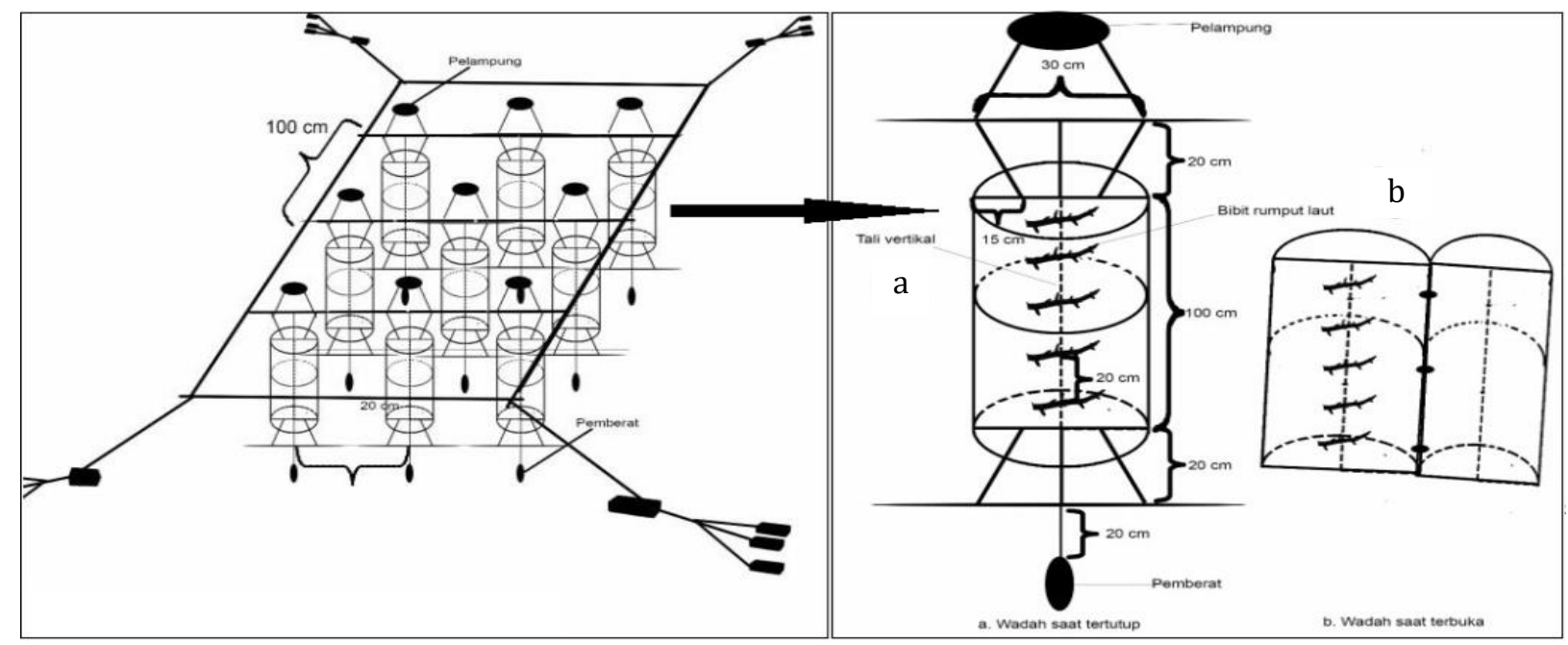

Gambar2 Budi daya rumput laut metode vertikultur menggunakan kurungan. 
terampil, dan terampil. Persentase penguasaan pengetahuan dan keterampilan ini disajikan dalam bentuk grafik batang dan dijelaskan secara deskriptif.

\section{HASIL DAN PEMBAHASAN}

Kegiatan pemberdayaan masyarakat dilaksanakan melalui kegiatan pelatihan dan pendampingan terhadap kegiatan budi daya rumput laut metode vertikultur menggunakan kurungan. Kegiatan budi daya rumput laut meliputi tahap sosialisasi/pengenalan budi daya rumput laut metode vertikultur, persiapan dan penanaman budi daya rumput laut, serta perawatan dan pengukuran kualitas air.

\section{Penyuluhan Budi Daya Rumput Laut Metode Vertikultur}

Tingginya nilai ekspor rumput laut mencapai $80 \%$ supply share terutama jenis eucheuma cottoni, dengan tujuan utama ke China. Merujuk data FAO (2019) bahwa ekspor rumput laut Indonesia ke China hampir 80\% masih didominasi raw material. Untuk itu penting menaikan nilai tambah devisa ekspor dengan menggenjot ekspor non raw material, paling tidak $50 \%$ bisa diekspor dalam bentuk setengah jadi seperti semi refine carrageenan dan refine carrageenan (Humas Ditjen Perikanan Budidaya 2020). Dengan adanya permintaan ekspor ini memerlukan dukungan kegiatan yang memacu produksi rumput laut, namun sampai saat ini kegiatan budi daya rumput laut umumnya masih menggunakan metode long line, dimana bagian permukaan perairan saja yang dimanfaatkan sebagai lahan budi daya, di sisi lain rumput laut masih dapat berkembang pada kolom air yang lebih dalam sepanjang masih terdapat sinar matahari yang dibutuhkan oleh rumput laut untuk berfotosintesis. Oleh karena itu, mulai dikembangkan metode baru dalam kegiatan pembudidayaan rumput laut, yaitu dengan vertikultur. Metode vertikultur merupakan kegiatan budi daya dengan menggunakan tali sebagai pengikat bibit rumput laut dalam posisi vertikal (tegak lurus) tujuannya untuk memanfaatkan kolom perairan sampai batas kecerahan perairan (Syahlun et al. 2013; PongMasak \& Sarira 2016).

Berkaitan dengan permasalahan yang dihadapi di Desa Rambu-rambu maka kegiatan KKN-PPM mencoba mengenalkan salah satu metode budi daya rumput laut. Kegiatan pengenalan ini dilaksanakan melalui kegiatan sosialisasi/penyuluhan tentang budi daya rumput laut metode vertikultur menggunakan kurungan. Tujuan kegiatan ini adalah 1) Meningkatkan pengetahuan pada petani rumput laut khususnya dan masyarakat Desa Ramburambu umumnya tentang metode budi daya rumput laut secara vertikultur menggunakan kurungan dan 2) Terjadi peningkatan pendapatan dan kesejahteraan petani rumput laut. Kegiatan ini dilakukan pada tanggal 11 Juli 2019 bertempat di Balai Desa Rambu-rambu. Kegiatan sosialisasi ini melibatkan tim ahli/dosen dan mahasiswa KKN-PPM dari FPIK UHO. Peserta sosialisasi adalah petani rumput laut dan masyarakat umum dari Desa Rambu-rambu (Gambar 3).

Metode vertikultur mulai diuji coba di Kabupaten Barru (Sulawesi Selatan) pada tahun 2009 oleh Balai Penelitian dan Pengembangan Budidaya Air Payau (BPPBAP) dan dilanjutkan pengembangannya oleh Loka Penelitian dan Pengembangan Budidaya Rumput Laut (LP2BRL) pada tahun 2013 sampai sekarang ini. Metode vertikultur mulai dikembangkan di Kabupaten Boalemo (Gorontalo) tahun 2013-2014, dan Kabupaten Buton Tengah (Sulawesi Tenggara) tahun 2015 (Pong-Masak \& Sarira 2015; PongMasak \& Sarira 2018).

Pengembangan budidaya rumput laut dengan teknik vertikultur memiliki kelebihan antara lain dapat memanfaatkan kolom perairan, rumput laut cukup menerima sinar matahari, lebih tahan terhadap perubahan kualitas air, terbebas dari hama yang biasanya menyerang dari dasar perairan, selain itu. Budi daya dengan metode ini cara kerjanya lebih mudah, biayanya lebih murah dan kualitas rumput laut yang dihasilkan baik (Aslan \& Rahman 2010).

\section{Persiapan dan Penanaman Budi Daya Rumput Laut}

Persiapan dan penanaman budi daya rumput laut dilaksanakan sejak kedatangan peserta KKN

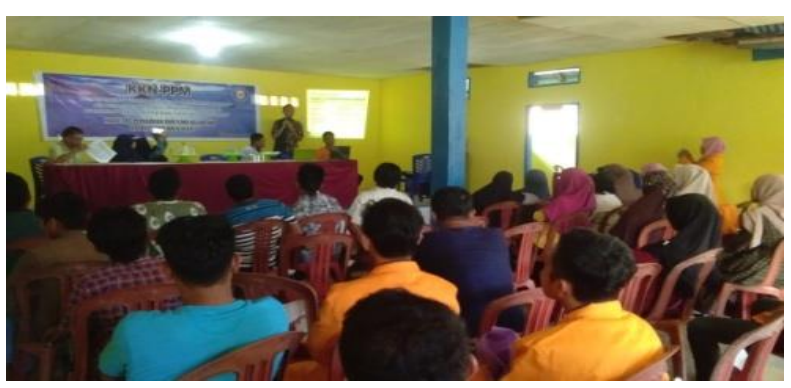

Gambar 3 Sosialisasi dan pengenalan budi daya rumput laut metode vertikultur. 
PPM, yaitu mulai tanggal 30 Juni-14 Juli 2019. Kegiatan tersebut meliputi 1) Pembuatan kurungan rumput laut; 2) Pembuatan pemberat; 3) Pembuatan rakit rumput laut dan pembentangan tali rakit; 4) Penurunan pemberat budi daya rumput laut; 5) Pengikatan rumput laut pada tali vertikal; dan 6) Penurunan kurungan budi daya rumput laut. Kegiatan ini dilaksanakan oleh mahasiswa KKN PPM bersama dengan masyarakat Desa Rambu-rambu. Mahasiswa KKN PPM bersama masyarakat Desa Rambu-rambu melakukan kegiatan persiapan dan penanaman rumput laut bersama-sama mulai dari pembuatan kurungan rumput laut sampai dengan penurunan kurungan budi daya rumput laut, selain itu kegiatan pengamatan pertumbuhan rumput laut dilakukan bersama-sama masyarakat (Gambar 4).

\section{Perawatan dan Pengukuran Kualitas Air}

Setelah penanaman dilakukan perawatan setiap tiga hari sekali dan pengukuran kualitas air setiap seminggu sekali. Hal ini dilakukan untuk mencapai hasil yang optimal dari kegiatan ini. Kegiatan budi daya ini berlangsung selama 30 hari. Kegiatan perawatan meliputi pembersihan kurungan rumput laut dari alga-alga menempel dan pemotongan thallus rumput laut dari penyakit ice-ice, selain kegiatan perawatan dilakukan juga pengukuran kualitas air dan penimbangan berat rumput laut (Gambar 5).

Pengukuran kualitas air pada kegiatan ini dilakukan untuk mengetahui kisaran kualitas air yang masih ditolerir dan dapat mendukung kehidupan dan pertumbuhan budi daya rumput laut. Hasil analisis kualitas lingkungan perairan disajikan pada Tabel 2. Hasil pengukuran kualitas air menunjukkan kisaran yang masih dapat ditolerir oleh budi daya rumput laut. Lama waktu pemeliharaan budi daya rumput laut pada kegiatan ini 30 hari, hal ini disebabkan hasil budi daya rumput laut ini diperuntukan untuk dijadikan bibit untuk kegiatan budi daya rumput laut lagi. Penimbangan rumput laut dimaksudkan

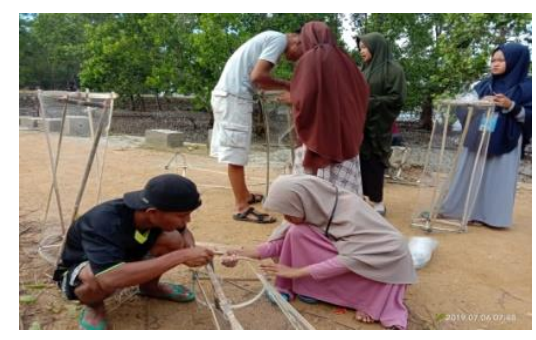

a

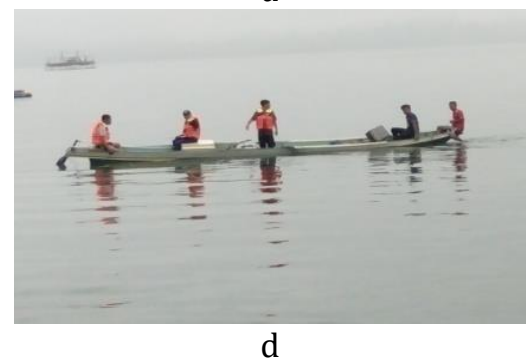

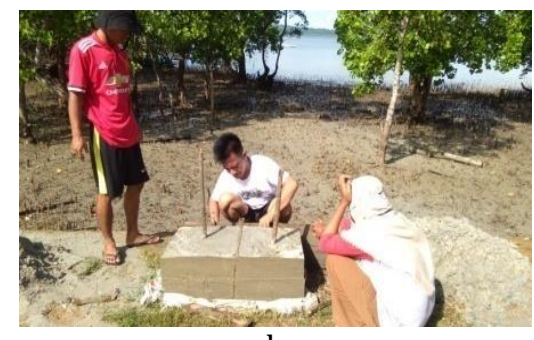

b

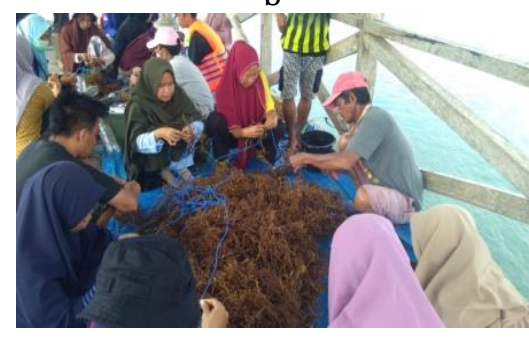

$\mathrm{e}$

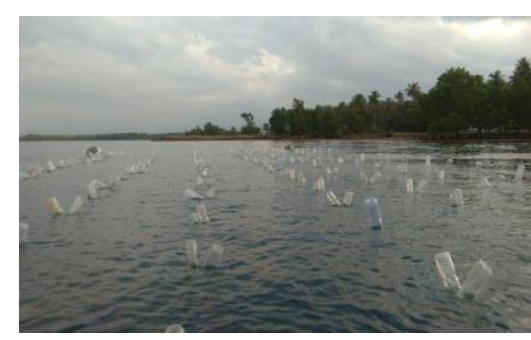

C

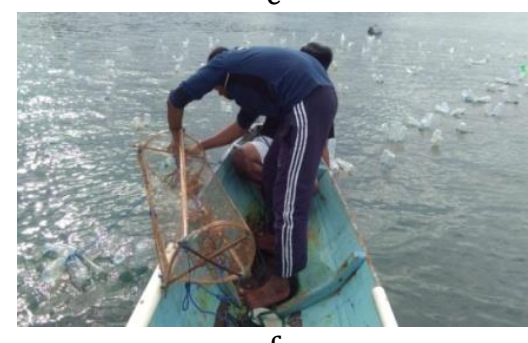

f

Gambar 4 Persiapan dan penanaman budi daya rumput laut:a)Pembuatan kurungan rumput laut; b) Pembuatan pemberat; c) Pembuatan rakit rumput laut dan pembentangan tali rakit; d) Penurunan pemberat budi daya rumput laut; e) Pengikatan rumput laut pada tali vertikal; dan f) Penurunan kurungan budi daya rumput laut.

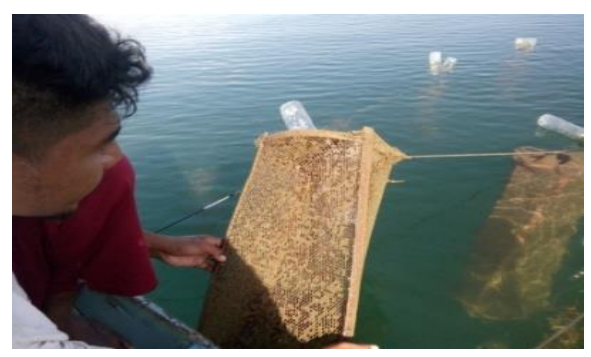

a

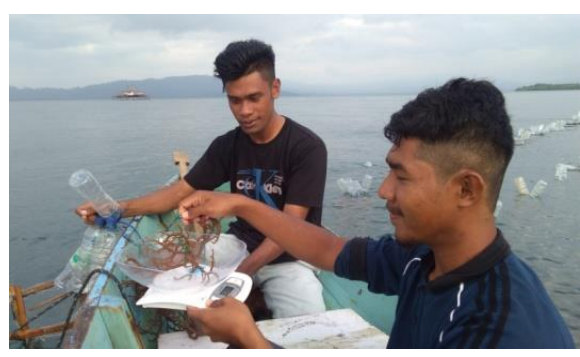

b

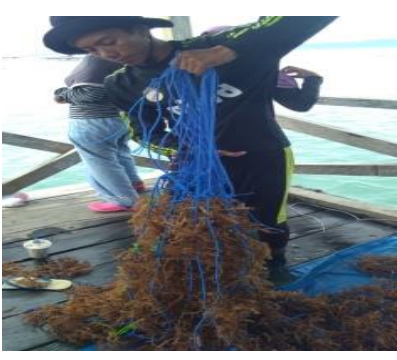

C

Gambar 5 Perawatan dan pemanenan budi daya rumput laut: a) Pembersihan kurungan rumput laut; b) Penimbangan rumput laut; dan c) Pengambilan hasil rumput laut sebagai bibit. 
untuk memantau apakah terjadi kenaikan berat rumput laut yang ditanam. Hasilnya menunjukkan peningkatan berat dari berat awal berkisar antara 52-78\%. Penelitian yang dilakukan oleh Wijayanto et al. 2019 menunjukkan bahwa pertumbuhan rumput laut Kappaphycus alvarezii jarak tanam antar rumpun $25 \mathrm{~cm}$ memiliki laju pertumbuhan harian lebih tinggi yaitu 2,13\% per hari.

\section{Capaian Program KKN-PPM}

Capaian program dari kegiatan KKN PPM yang dilaksanakan menunjukkan adanya peningkatan pengetahuan dan keterampilan masyarakat tentang budi daya rumput laut metode vertikultur menggunakan kurungan. Peningkatan pengetahuan dan keterampilan selama kegiatan diperoleh pengetahuan masyarakat sebelum kegiatan sebanyak $66,7 \%$ tidak paham, setelah dilakukan kegiatan menjadi sebanyak $71,4 \%$ yang paham terhadap budi daya rumput laut metode vertikultur. Penguasaan keterampilan diperoleh peningkatan dari sebelum kegiatan sebanyak 81\% tidak terampil dan setelah kegiatan menjadi sebanyak 61,9\% yang terampil dalam kegiatan budi daya rumput laut metode vertikultur (Gambar 6). Peningkatan pengetahuan masyarakat ini terlihat dari mampunya mereka menjelaskan dengan baik tentang jenisjenis rumput laut, manfaat dari rumput laut, dan ciri-ciri bibit rumput laut yang baik untuk budi daya. Sedangkan peningkatan keterampilan terlihat dari kemampuan mereka dalam membuat rakit budi daya rumput laut, kurungan rumput laut, pengikatan bibit rumput laut, dan pengamatan kualitas perairan di area budi daya rumput laut.

\section{Kendala dan Keberlanjutan Program}

Kegiatan KKN-PPM di Desa Rambu-rambu dalam pelaksanaanya menghadapi beberapa kendala, yaitu salah satunya menyangkut ketersediaan bibit rumput laut yang sangat terbatas, sehingga untuk memperoleh bibit rumput laut sangat tergantung dari ketersediaan bibit di kecamatan lainnya. Selain itu, jarak tempuh untuk mendapatkan bibit rumput laut sangat jauh, sehingga membutuhkan biaya yang sangat tinggi dalam hal transportasi. Kendala tersebut dapat diselesaikan dengan cara hasil

Tabel 2 Data kualitas air di areal budi daya rumput laut

\begin{tabular}{lcrrrr}
\hline \multirow{2}{*}{ Paremeter } & \multirow{2}{*}{ Satuan } & \multicolumn{4}{c}{ Pengamatan minggu ke- } \\
\cline { 3 - 6 } & & 1 & 2 & 3 & \multicolumn{1}{c}{4} \\
\hline Suhu & ${ }^{0} \mathrm{C}$ & 31,00 & 32,00 & 32,00 & 31,00 \\
Salinitas & $\mathrm{o} / \mathrm{oo}$ & 31,00 & 32,00 & 32,00 & 31,00 \\
$\mathrm{pH}$ & & 7,00 & 7,00 & 7,00 & 7,00 \\
Kecerahan & $\mathrm{m}$ & 12,50 & 11,00 & 15,50 & 14,50 \\
Kecepatan arus & $\mathrm{m} / \mathrm{dtk}$ & 0,17 & 0,03 & 0,02 & 0,05 \\
Nitrat & $\mathrm{mg} / \mathrm{L}$ & 0,20 & 0,18 & 0,12 & 0,11 \\
Ortofosfat & $\mathrm{mg} / \mathrm{L}$ & 0,08 & 0,06 & 0,07 & 0,04 \\
\hline
\end{tabular}

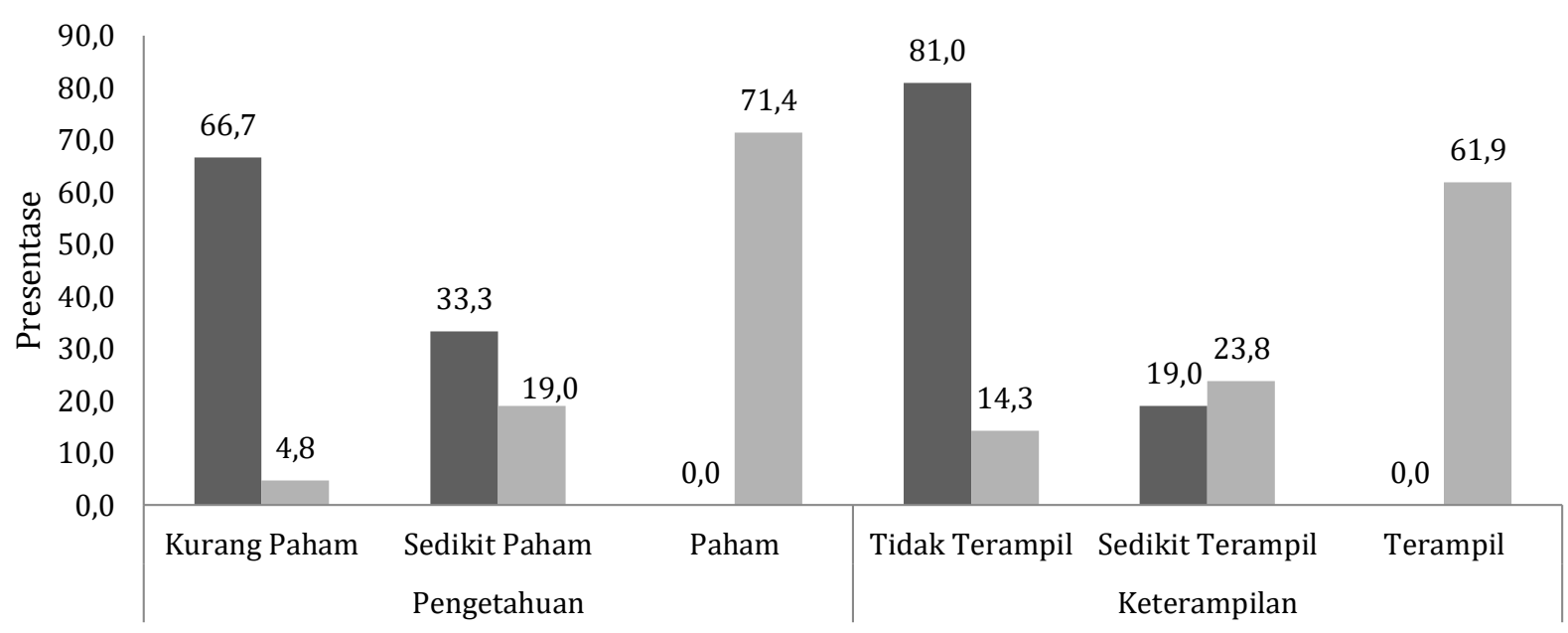

- Sebelum Pelaksanaan KKN-MMP

- Setelah Pelaksanaan KKN-PPM

Gambar 6 Presentase penguasaan pengetahuan dan keterampilan sebelum dan sesudah pelaksanaan KKN-PPM. 
dari kegiatan budi daya rumput laut yang dilaksanakan oleh KKN PPM dapat dijadikan bibit lagi oleh petani rumput laut di Desa Ramburambu.

Kegiatan KKN PPM yang melibatkan tim pengabdian dari FPIK UHO, mahasiswa, dan masyarakat Desa Rambu-rambu diharapkan dapat berlangsung secara berkelanjutan. Program ini diharapkan dapat betul-betul diimplementasikan secara kontinu oleh kelompok sasaran mitra secara khusus dan masyarakat Desa Rambu-rambu pada umumnya. Karena segala penerapan teknologi dan aplikasi yang diberikan kepada masyarakat dapat digunakan untuk menyokong perekonomian di Desa Rambu-rambu.

Setelah melaksanakan beberapa kegiatan pada pelaksanaan program KKN-PPM tersebut, maka diperoleh hasil dan rumusan masalah yang kemudian menjadi dasar dalam perencanaan dan strategi untuk tahapan berikutnya. Agar kegiatan ini dapat berlangsung secara berkelanjutan, maka pelibatan atau partisipasi aktif dari masyarakat adalah kunci utama. Terdapat beberapa perencanaan dan strategi agar kegiatan ini dapat berlangsung secara bekelanjutan, yaitu :

- Peningkatan pengetahuan dan teknologi dalam hal penanganan dan penyediaan bibit rumput laut, sehingga petani rumput laut di Desa Rambu-rambu tidak lagi tergantung dengan kesediaan bibit dari desa lainnya.

- Peningkatan pengetahuan dan teknologi dalam hal penanganan hasil panen budi daya rumput laut. Hasil rumput laut yang dipanen tidak hanya dalam bentuk rumput laut kering, tetapi sudah dalam bentuk tepung dan juga dalam bentuk olahan siap pakai.

- Kelompok sasaran yang mengikuti kegiatan secara langsung akan dijadikan desa binaan oleh dosen FPIK. Hal tersebut ditunjang dengan adanya dana desa sehingga program yang telah berjalan akan dijadikan program desa di tahun berikutnya khususnya di bidang kemaritiman.

\section{SIMPULAN}

Kegiatan KKN PPM di Kawasan Perdesaan Tumbuh Lestari Desa Rambu-rambu merupakan kegiatan pemberdayaan kelompok masyarakat pesisir melalui kegiatan budi daya rumput laut metode vertikultur. Kegiatan pemberdayaan ini meliputi penyuluhan, persiapan training, dan pelaksanaan training tentang cara budi daya rumput laut metode vertikultur menggunaan kurungan. Capaian program dari kegiatan KKN PPM yaitu peningkatan pengetahuan dan keterampilan masyarakat tentang budi daya rumput laut metode vertikultur menggunakan kurungan.

\section{UCAPAN TERIMA KASIH}

Kegiatan KKN PPM ini terlaksana atas pembiayaan dari Direktorat Riset dan Pengembangan Masyarakat, Direktorat Jenderal Penguatan Riset dan Pengembangan Kemenristekdikti sesuai dengan Kontrak Pengabdian Kepada Masyarakat Program KKN PPM Universitas Halu Oleo Tahun Anggara 2019 Nomor 588 /UN29.20/PPM/2019, tanggal 26 Maret 2019. Oleh karena itu kami sebagai pelaksana kegiatan KKN PPM mengucapkan terima kasih yang sebesar-besarnya kepada Lembaga Penelitian dan Pengabdian Kepada Masyarakat, Universitas Halu Oleo, perusahaan rumput laut, Pemerintah Daerah Kecamatan Kolono Timur, Kepada Desa Ramburambu dan jajaran, Masyarakat Desa Ramburambu, serta mahasiswa peserta KKN PPM (20 orang) yang telah banyak membantu kelancaran kegiatan pengabdian ini.

\section{DAFTAR PUSTAKA}

Aslan LM, Rahman A. 2010. Pengaruh Jarak Tanam dan Bobot Bibit yang Berbeda Terhadap Pertumbuhan Rumput Laut Varietas Merah Jenis Kappaphycus alvarezii dengan Menggunakan Metode Vertikultur. Jurnal Aqua Hayati. 7(1) :10-18.

Aslan LM, Rahman A. 2010b. Pengaruh Jarak Tanam Bibit yang Berbeda Terhadap Pertumbuhan dan Kadar Karaginan Rumput Laut (Kappaphycus alvarezii) Varietas Cokelat dengan Metode Long Line. Jurnal Aqua Hayati. 7(2): 16-23.

Humas DITJEN Perikanan Budidaya. 2020. Siaran Pers Genjot Nilai Ekspor KKP Target Produksi 10,99 Juta Ton Rumput Laut. [Internet]. [Diunduh 31 Maret 2020]. Tersedia pada: https://kkp.go.id/artikel/16505-genjot-nilaiekspor-kkp-targetkan-produksi-10-99-jutaton-rumput-laut-di-2020). 
Kemendesa. 2017. Rencana Pengembangan Kawasan Perdesaan Kabupaten Konawe Selatan. [Internet]. [Diunduh 8 September 2019]. Tersedia pada: http://rpkp.org/listings/kab-konaweselatan/.

Pong-Masak PR, Sarira NH. 2018. Penentuan Jarak Tanam Optimal Antar Rumpun Bibit pada Metode Vertikultur Rumput Laut. Jurnal Perikanan Universitas Gadjah Mada. 20 (1): 23-30. https://doi.org/10.22146/jfs.33310

Pong-Masak PR, Sarira NH. 2015. Petunjuk Teknis Teknologi Budidaya Rumput Laut Kappaphycus alvarezii dengan metode vertikultur. Gorontalo (ID): Loka Riset Budi Daya Rumput Laut.
Pong-Masak PR, Sarira NH. 2016. Pertumbuhan dan produksi rumput laut Kappaphycus alvarezii dengan aplikasi metode vertikultur di Kabupaten Buton Tengah, Provinsi Sulawesi Tenggara. Dalam: Prosiding Forum Inovasi Teknologi Akuakultur.

Syahlun, Rahman A, Ruslaini. 2013. Pertumbuhan Rumput Laut (Kappaphycus alvarezii) Strain Cokelat dengan Metode Vertikultur. Jurnal Mina Laut Indonesia. 1(1): 122-132.

Wijayanto TH, Ilham, Purwanti TA. 2019. Teknik Budi daya Rumput Laut Kappaphycus Alvarezii Dengan Metode Vertikultur. Buletin Teknik Litkayasa Akuakultur. 7(2): 99-105. 